\title{
Searching For Signs of Life in Ontario Universities: An Innovative Method for Evaluating Biodiversity Integration within University Curricula
}

Jenn McCallum

Trent University

Paul Elliott

Trent University

Terese McIntosh

Ontario Ministry of Natural Resources and Forestry

\begin{abstract}
This study investigates the degree to which biodiversity concepts are included within university curricula in Ontario and provides a baseline for tracking this. A keyword search of undergraduate and graduate academic calendars from six Ontario universities was conducted. A list of 28 relevant keywords was developed, and university program descriptors were searched for these keywords, while considering core and elective courses within each program. Almost half (49.5\%) of the 386 undergraduate programs, and $29.4 \%$ of the 327 graduate programs featured biodiversity keywords. Science programs showed the highest degree of integration $(74.5 \%$ for undergraduate and $37.4 \%$ for graduate programs), followed by business programs (57.6\% and $38.4 \%$, respectively). The arts and social sciences showed the least biodiversity integration (25.8\% of undergraduate and $21.0 \%$ of graduate programs). This research method provides a depth of understanding of biodiversity integration within university curricula, although the analysis is limited to the content provided in academic calendars.
\end{abstract}




\section{Résumé}

Cette étude évalue le degré d'intégration des concepts de la biodiversité dans les programmes universitaires en Ontario, et établit des repères pour suivre cette intégration. Une recherche par mots-clés a été réalisée dans les calendriers des cours de premier cycle et de cycles supérieurs de six universités ontariennes. Nous avons dressé une liste de 28 mots-clés pertinents, puis avons effectué une recherche de ces mots-clés parmi les descripteurs de programmes universitaires, en englobant les cours obligatoires et facultatifs de chaque programme. Près de la moitié (49,5\%) des 386 programmes de premier cycle et 29,4\% des 327 programmes de cycles supérieurs étaient assortis de mots-clés liés à la biodiversité. Parmi tous les programmes, les programmes scientifiques ont démontré le degré d'intégration le plus élevé (74,5\% pour le premier cycle et $37,4 \%$ pour les cycles supérieurs), suivis des programmes en commerce ( $57,6 \%$ pour le premier cycle et $38,4 \%$, pour les cycles supérieurs). Par ailleurs, les arts et les sciences sociales ont démontré la plus faible intégration de la biodiversité (25,8 \% pour le premier cycle et 21,0 \% pour les cycles supérieurs). Cette méthode de recherche permet de mieux comprendre l'intégration de la biodiversité dans les programmes universitaires, même si l'analyse se limite au contenu indiqué dans les calendriers des cours.

\section{Introduction}

All life on Earth, including human life, is dependent on other life forms and "the history of life on earth has been a history of interaction between living things and their surroundings" (Carson, 1962, p. 5). Biodiversity is the term used to describe the variety of living things, the word first appearing in print in 1988 as a contraction of the term "biological diversity." The Convention on Biological Diversity defines biological diversity as "the variability among living organisms from all sources including, inter alia, terrestrial, marine and other aquatic ecosystems, and the ecological complexes of which they are part; this includes diversity within species, between species and of ecosystems" (United Nations, 1992, p.3).

It is known that at least five times in geological history mass extinctions have radically reduced biodiversity at the species level with at least $75 \%$ of species becoming extinct in each case (Monastersky, 2014). There is now considerable evidence to indicate we are entering a sixth period of mass extinction and that anthropogenic impacts (i.e., human activities) are the prime cause. It is estimated that current extinction rates are at least 100 to 1,000 times greater than the normal extinction rate (Baillie, Hilton-Taylor, \& Stuart, 2004; Pimm et al., 2014) with 500 to 3,600 species becoming extinct each year (Monastersky, 2014). A multitude of factors are thought to be responsible, but habitat loss and unsustainable harvesting of natural resources are considered the major causes (Baillie et al., 2004), and it is anticipated that climate change will only exacerbate matters (Secretariat of the Convention on Biological Diversity, 2007).

Ironically, one of the main strategies available to us to reduce the impacts of climate change is the proper management and conservation of biodiversity (Secretariat of the Convention on Biological Diversity, 2007). Although most governments are taking mea- 
sures to protect increasingly large areas of land and sea, the overall pressures on biodiversity are thought to be increasing because of population growth and economic development (Monastersky, 2014; Secretariat of the Convention on Biological Diversity, 2014). This matters because, as E. O. Wilson put it in his 1992 seminal book The Diversity of Life, "Biological diversity is the key to the maintenance of the world as we know it" (p.12).

The Convention on Biological Diversity was launched at the United Nations Conference on Environment and Development, the so-called Rio Earth Summit, in 1992. Canada ratified the convention on December 4, 1992, and it was implemented in December 1993. Article 13 of the convention calls on parties to promote public education on and awareness of the importance of the conservation and sustainable use of biological diversity (United Nations, 1992; Secretariat of the Convention on Biological Diversity, 2008). In order to further promote policies to safeguard biodiversity, the United Nations identified targets for biodiversity at the Aichi meeting, which launched the Strategic Plan for Biodiversity 2011-2020 and declared 2011-2020 the Decade on Biodiversity (United Nations, 2014). The twenty Aichi Biodiversity Targets fall under five strategic goals:

1. to address the underlying causes of biodiversity loss by mainstreaming biodiversity across government and society

2. to reduce the direct pressures on biodiversity and promote sustainable use

3. to improve the status of biodiversity by safeguarding ecosystems, species, and genetic diversity

4. to enhance the benefits to all from biodiversity and ecosystem services, and

5. to enhance implementation [of the targets] through participatory planning, knowledge management and capacity building (United Nations, n.d.).

The United Nations (n.d.) has stated that "Address[ing] the underlying causes of biodiversity loss [will involve] mainstreaming biodiversity across government and society."

Canada responded to the Aichi Biodiversity Targets by developing national biodiversity goals and targets for 2020 (Biodiv Canada.ca, 2015). The intention was to help focus attention on domestic biodiversity priorities and provide the basis for measuring and reporting on progress. Goal D of the Biodiversity Goals and Targets for Canada states that by 2020, "Canadians [will be] informed about the value of nature and more actively engaged in its stewardship." Target 18 specifically states that by 2020, "biodiversity is integrated into the elementary and secondary school curricula" (Biodiv Canada.ca, 2014). There is, however, no mention of integrating biodiversity into postsecondary education.

The province of Ontario is home to 35\% of Canada's population and is a major economic region within Canada, with all the associated pressures on its native biodiversity that this brings (Ontario Biodiversity Council, 2011). Ontario has been subject to major land use changes since the onset of European settlement. Deforestation, wetland drainage, eutrophication, acidification, and industrial and urban development have contributed to losses in natural habitat. A dramatic example of this is the reduction of prairie and savannah habitat, which once accounted for over two million hectares of Ontario, but these habitats are now considered rare ecosystems because only 2,100 hectares survive today (Ontario Biodiversity Council, 2010; High Park Nature, 2014). The economic importance of Ontario and its land use changes have had major implications for its biodiversity, with 224 species at risk currently identified by the Ontario Ministry of Natural Resources and Forestry (2014). 
Despite the degradation suffered by Ontario's habitats and loss of species diversity, it is unclear how committed the public are to taking practical action to address the problem. A survey of selected conservation organizations that maintain volunteer databases led to the estimate that only $0.3 \%$ of the province's population volunteer their time to assist with conservation projects (Ontario Biodiversity Council, 2010). By contrast a questionnaire survey conducted by Statistics Canada (2015a) found that 20\% of the Ontario households surveyed claimed to have engaged in unpaid activities aimed at conservation or protection of the environment or wildlife. Clearly there will also be people who make financial contributions towards habitat and species conservation efforts, such as the Ontarians who are among the 300,000 supporters of the Canadian Wildlife Federation (n.d.), although Grundy (2013) estimates that only $2 \%$ of charitable giving in Canada goes to such environmental causes.

Fifteen targets for biodiversity conservation in Ontario have been identified (Ontario Biodiversity Council, 2011). The first target reads: "By 2015, biodiversity [will be] integrated into the elementary, secondary and post-secondary school curricula, including schools of business" (Ontario Biodiversity Council, 2011, p. iii). Unlike the national biodiversity goals and targets, it specifically mentions postsecondary education in addition to primary and secondary education. The specific reference to business schools also stands out as unusual, yet appears to be in line with the United Nations' (2014) statement regarding the need to mainstream biodiversity into development policies. If students of business studies are educated about the need to protect biodiversity and ways to factor this into business planning, they can help to meet this objective. It is a stance that E. F. Schumacher would approve of. In his influential book Small Is Beautiful he wrote: "if we believe in nothing else, we certainly believe that education is, or should be, the key to everything" (Schumacher, 1973, p. 64).

The Council of Ontario Universities (COU) (2013) reported that 17 universities in the province offer sustainability-related (major) programs, 19 offer sustainability-related minors and 15 offer multidisciplinary degrees. They also reported that 15 offered Masters degrees in sustainability-related fields. In all cases, these programs were described as being available across a wide range of disciplines. What is not made clear in the COU report is the proportion of programs these offerings represent or to what extent they can be related to the theme of biodiversity. For example, while all of the universities have programs in biology, not all of these include ecology content.

The scope of what may be considered biodiversity education is necessarily broad because, as Kassas (2002) points out, biodiversity can mean different things to different people, all of whom perceive its value in a variety of ways, some of which are anthropocentric (human focused) and some biocentric (focused on all life forms). This breadth of perspectives means that there is a broad swath of opportunities to incorporate biodiversity-related content into diverse academic disciplines. The purpose of this research is to assess the degree to which Ontario universities have succeeded in doing this and to identify areas where more work is needed.

\section{Methods}

This research was conducted on behalf of the Ontario Biodiversity Council (OBC) and aimed to produce baseline data for Target 1 so that it can be tracked over time: "By 2015 , 
biodiversity [will be] integrated into the elementary, secondary and post-secondary school curricula, including schools of business" (Ontario Biodiversity Council, 2011, p. iii).

In Ontario, a university's academic calendar is updated annually and lists all courses currently offered by a university, providing an approximately 50-word description of each. A keyword search and scan was performed on undergraduate and graduate academic calendars from six Ontario universities, between April and September 2014. These six universities represent $30 \%$ of the 20 Ontario universities and $6.1 \%$ of Canadian universities (Ontario Universities' Application Centre, 2015). The universities were Carleton, Lakehead, Guelph, Toronto, Trent, and Ontario Institute of Technology. They were selected to provide a representative sample based on geographic range, size (student enrolment), and diversity of program offerings. The universities are distributed in western, central, and eastern regions of the province (Figure 1), although most are within the boundaries of southern Ontario, due to the concentrated human population in this area. We also included Lakehead in the sample to maximize geographic range because its main campus is the most northerly university in the province.

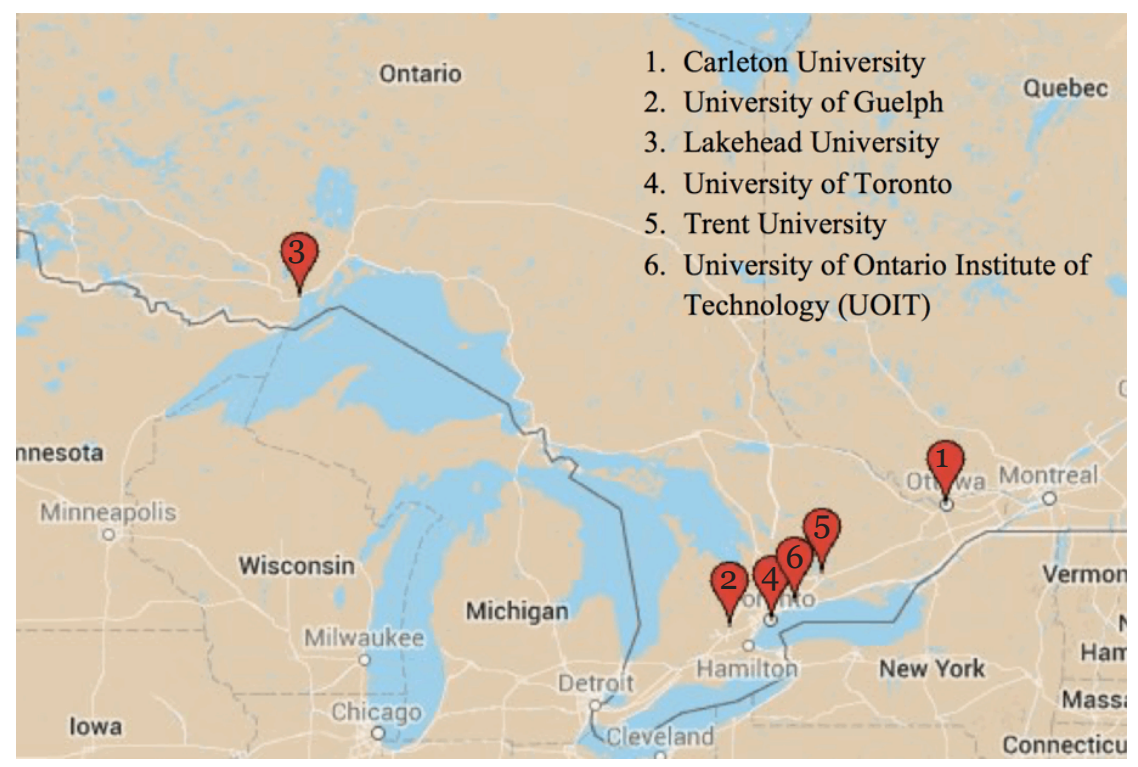

Figure 1. Map of the six universities studied. (Source: Google Maps, 2014.)

The total enrolment at the six universities was nearly 158,00o students at the time of this study (Table 1). This represents $35 \%$ of the total 456,460 undergraduate and graduate students enrolled in Ontario universities (Council of Ontario Universities, 2014). In addition, these six universities total enrolment of 158,000 students represents nearly onetenth (9.3\%) of the total 1,700,000 students enrolled in Canada (Universities Canada, 2015). It is also worth noting that $38 \%$ of Canada's population resides in Ontario (Statistics Canada, 2015b), and this province is highly important to the economic and political activities within the county.

The range of universities includes small (enrolment under 10,000 students), medium (20,000 to 30,000 students) and large (enrolment over 30,000) institutions. This categorization by size is similar to the one used by Maclean's magazine (Dwyer, 2013) in its annual ranking of Canadian universities. 
Table 1. Student Enrolment by University

\begin{tabular}{lc}
\hline University & Student Enrolment \\
\hline Trent University & 8,120 \\
Lakehead University & 8,680 \\
University of Ontario Institute of Technology & 9,600 \\
University of Guelph & 20,500 \\
Carleton University & 28,000 \\
University of Toronto & 83,010 \\
Total student enrolment & $\mathbf{1 5 7 , 9 1 0}$ \\
\hline
\end{tabular}

Sources:

Carleton University (n.d.-a). History. Retrieved from http://carleton.ca/about/history

Carleton University. (n.d.-b). About Carleton: Canada's capital university. Retrieved from http://carleton. ca/about/

Lakehead University. (2012). About Lakehead University. Retrieved from https://www.lakeheadu.ca/ about/overview

Trent University. (n.d.). About Trent: Trent facts. Retrieved from http://www.trentu.ca/about/facts.php

University of Guelph. (n.d.). How many students are enrolled in the university? Retrieved from http:// askgryph.registrar.uoguelph.ca/?requestType $=$ NormalRequest\&source $=4 \& i d=53 \& q u e s t i o n=H o w+$ man $\mathrm{y}+$ students+are+enrolled+in+the+University

University of Guelph. (2015). Historical timeline. Retrieved from http://www.uoguelph.ca/5o/history/

University of Ontario Institute of Technology. (n.d.). Fact sheet. Retrieved from http://uoit.ca/about/uoitinfo/fact-sheet.php

University of Toronto. (n.d.). History \& traditions. Retrieved from http://www.utoronto.ca/about-uoft/ history-traditions

University of Toronto. (2014a). Quick facts. Retrieved from http://www.utoronto.ca/about-uoft/quickfacts

The undergraduate and graduate academic calendars of each university were accessed online and a keyword search and complete scan were conducted to determine whether biodiversity-related content appeared in the program descriptors (see Table 2 for a definition of the term "program").

Table 2. Definitions of University Programs and Core and Elective Courses

Program An assortment of courses that lead toward a degree at the undergraduate or graduate level. Programs consist of a certain number of core and elective courses. Programs were grouped into three categories: sciences, business, and arts. (Table 4 provides a detailed description of how programs were grouped into these categories.)

Core course A course that is required within a particular undergraduate or graduate program.

Elective A course that is not required but is optional to take within a particular program. course

Restricted In the case of restricted electives, students have the option to take one or more elective courses within a list of several elective courses. For example, a program may course specify that students must choose one course from a list of three elective courses. 
Some of the academic calendars (University of Guelph, 2014; University of Toronto, 2014b \& c; Trent University, 2014; University of Ontario Institute of Technology, 2014) were available in PDF format from the university websites and in these cases the scanning and keyword search was conducted using Mendeley. For Carleton (2014a \& b) and Lakehead (2014) universities, the scanning and keyword searching were conducted using their online academic calendars because there was no PDF available. The list of keywords is available in Table 3.

Table 3. List of Keywords Used to Search University Academic Calendars for Biodiversity Education Content

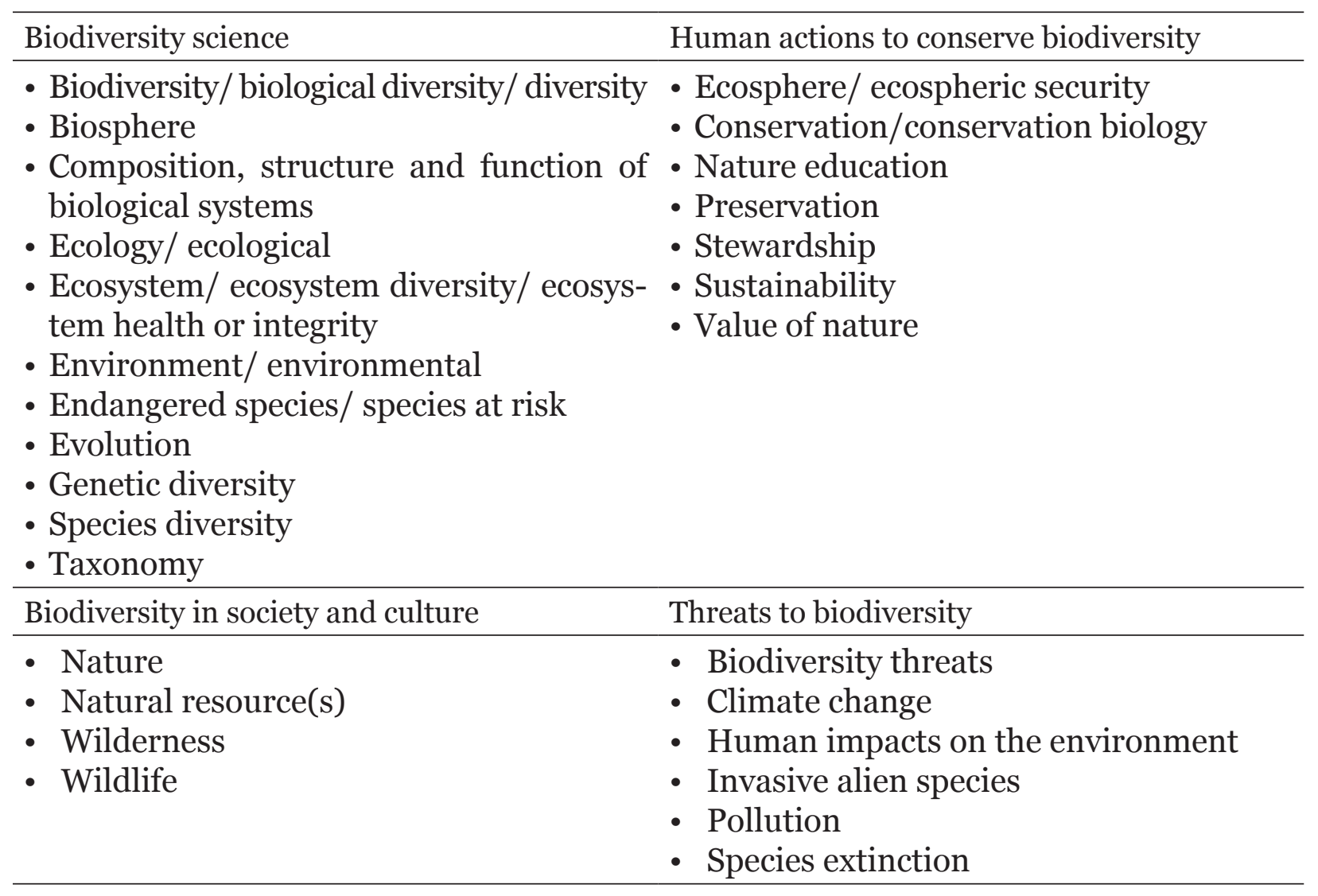

Most of the keywords used in the document analysis were generated by panel participants working on behalf of the OBC. A few additional keywords emerged through the process of examining the university academic calendars. Some of these keywords refer more to human impacts on and attitudes toward nature than with a narrow examination of biodiversity. This broader interpretation was intentional, because the OBC considered the wider anthropogenic (i.e., human-caused) impacts on biodiversity as relevant to this research (e.g., climate change and habitat loss). The complete scan of academic calendars was also employed in this research to check for the presence of multiple keywords at the same time and to ensure that the context in which keywords appeared accurately represented biodiversity integration. For example, an education course description mentioning the "learning environment," a visual arts course discussing the "conservation" of artistic 
masterpieces, or a course in computer science that mentions "the online environment" are clearly not referring to biodiversity content. Most such words were easy to identify from their context, but in a few cases we had to dig deeper into online information. In a handful of cases the OBC panel were asked to adjudicate on whether the key words were likely to relate to biodiversity.

Courses were considered to include biodiversity concepts if they featured at least one of the keywords identified in Table 3 and whether or not the context suggested reference to the natural environment. A binary system was employed so that courses featuring one or more keyword(s) used in the appropriate context were assessed as having biodiversity content, whereas courses not including keywords, or featuring keywords out of context, were recorded as lacking biodiversity content.

The use of a keyword search of academic calendars is similar to the methods used by Smith, Bazely, and Yan (2011) and Lozano and Peattie (2009). However, Smith et al. (2011) focused exclusively on invasive alien species education at the postsecondary level and while invasive species influence biodiversity, the present study takes a broader approach to understanding biodiversity education at the postsecondary level. In addition, the present research employed a complete scan of academic calendars for the use of multiple keywords, making it a more in-depth analysis of program and course content than the research of Smith et al. (2011). Lozano and Peattie's (2009) STAUNCH (Sustainability Tool for Assessing Universities Curricula Holistically) technique was used to assess the contribution of several universities' curricula to sustainable development (e.g., Lozano \& Peattie, 2011). While the STAUNCH technique involves the similar analysis of course descriptions, it focuses on the slightly broader topic of education for sustainable development and has only been used within individual institutions, rather than in comparative studies.

Biodiversity integration is defined as the inclusion of biodiversity concepts within a university program, as evidenced by the presence of keywords within the program's course descriptions. Evaluating whether a specific program featured biodiversity-related content involved three steps. First, determining whether core or elective courses included the biodiversity-related keywords. This involved analyzing the content of approximately 18,000 university courses at the undergraduate and graduate levels. Second, the contextual use of each keyword was evaluated to determine whether or not it genuinely represented biodiversity content. Third, if there were several elective courses that included keywords, or at least one core course, then the overall program was considered to have biodiversity content (definitions of the terms "program," "core course," "elective course," and "restricted elective" are provided in Table 2.) Theoretically, any course offered within a university can be considered as a potential elective, but for the purposes of this study only those specifically listed as part of each program were considered. For example, a university ecology program might allow for a certain number of electives, but the only electives considered for biodiversity content were those recommended as components of the program.

If a core course within a program included a biodiversity keyword (used within an appropriate context), then the program was considered to have biodiversity content. If a number of elective courses featured biodiversity keywords or if restricted electives included keywords, then the program was thought to include biodiversity content. Programs where no core courses and where only one or two elective courses featured keywords were evaluated as lacking biodiversity content. 
A total of 386 undergraduate programs and 327 graduate programs were examined for biodiversity content. Programs were placed within one of three categories: sciences, business, arts and social sciences. Table 4 summarizes how programs were allocated to these categories. Some programs were difficult to assign, because while one institution may categorize it as a science, another may designate it as arts and social sciences. For example, anthropology and geography were sometimes featured as Bachelor of Science (BSc) programs and sometimes as Bachelor of Arts (BA) programs. Interdisciplinary programs were also difficult to categorize as either a sciences or an arts and social science category. For the purposes of this research, these programs were consistently assigned to specific categories. Business programs were considered as a stand-alone category because they were highlighted within the Target 1 of the Ontario Biodiversity Council's Biodiversity Strategy (2011).

Table 4. Summary of programs Included within Each Category: Sciences, Business, and Arts

\begin{tabular}{lll}
\hline Sciences & Business & Arts and Social Sciences \\
\hline Agriculture & Accounting & Architecture \\
Applied science & Administration & Anthropology \\
Biology & Business & Bachelor of Arts and Science \\
Bioinformatics & Commerce & Canadian studies \\
Biotechnology & Economics & Classics \\
Chemistry & Finance & Communication \\
Cognitive science & Hospitality & Criminology \\
Computer science & Management & Education \\
Conservation & Marketing & English \\
Earth science & Real estate and housing & Environmental studies \\
Engineering & Tourism & Geography \\
Environmental science & & History \\
Forensic science & & Humanities \\
Geographical Information & & Indigenous studies \\
Systems (GIS) & & \\
Geology & & Law \\
Gerontology & & Linguistics \\
Health science & & Media studies \\
Immunology & & Modern languages \\
Integrated science & & Music \\
Kinesiology & & Philosophy \\
Materials science & & Political science \\
Mathematics & & Psychology \\
Medicine & & Public health studies \\
Nanoscience & & Rural studies \\
& &
\end{tabular}




\begin{tabular}{|c|c|c|}
\hline Sciences & Business & Arts and Social Sciences \\
\hline Nanotechnology & & Social sciences \\
\hline Neuroscience & & Sociology \\
\hline Nutrition & & Theatre studies \\
\hline Nursing & & Visual studies \\
\hline Physics & & Women's and gender studies \\
\hline \multicolumn{3}{|l|}{ Statistics } \\
\hline \multicolumn{3}{|l|}{ Toxicology } \\
\hline Veterinary science & & \\
\hline
\end{tabular}

By far the most commonly used keyword in course descriptions was "environment" (and "environmental"), although sometimes this term was used in contexts that were not indicative of biodiversity education (as in the previous example) and were not counted. The term "sustainability" was also commonly used, especially within business programs. Other terms, such as taxonomy, endangered species, and ecosphere were uncommon in academic calendars. All of these keywords were considered for this study because the OBC had created the initial list and it was used to study the integration of biodiversity concepts within elementary and secondary school curricula as well (a separate study from the present one; see Ontario Biodiversity Council, 2015).

\section{Results}

Biodiversity integration within the curricula of the six sampled universities is summarized in Figure 2. Overall, $49.5 \%$ of undergraduate and $29.4 \%$ of graduate programs featured biodiversity-related content. Science programs showed the highest frequency of biodiversity integration, with $74.3 \%$ of undergraduate and $37.4 \%$ of graduate programs featuring course descriptors that included biodiversity keywords. Undergraduate and graduate level arts and social science programs integrated biodiversity concepts least frequently: $25.8 \%$ and $21.0 \%$, respectively. Business programs showed a frequency of $57.6 \%$ for undergraduate and $38.4 \%$ for graduate programs.

Life science programs showed the highest frequency of biodiversity integration. Some chemistry, physics, and engineering programs featured core courses with biodiversity descriptors, especially in some of their introductory courses (e.g., BIO120H1 Biodiversity and Adaptation at the University of Toronto).

Within the arts and social sciences programs, anthropology and geography showed the highest degree of biodiversity integration-often featuring courses that discuss human impacts on the environment (e.g., ANTH 3033 Society, Technology and the Environment and GEOG 3209 Sustainability and Environment at Carleton University). The most common biodiversity-related terms within business programs were "sustainability" and "environment," and courses often discussed life-cycle analysis or the impacts of business practices on the environment. Examples of such courses are ADMN 445OH Perspectives and Practices for Organizational Sustainability at Trent University, and TRMH 6250 Tourism and Sustainable Development at the University of Guelph. 


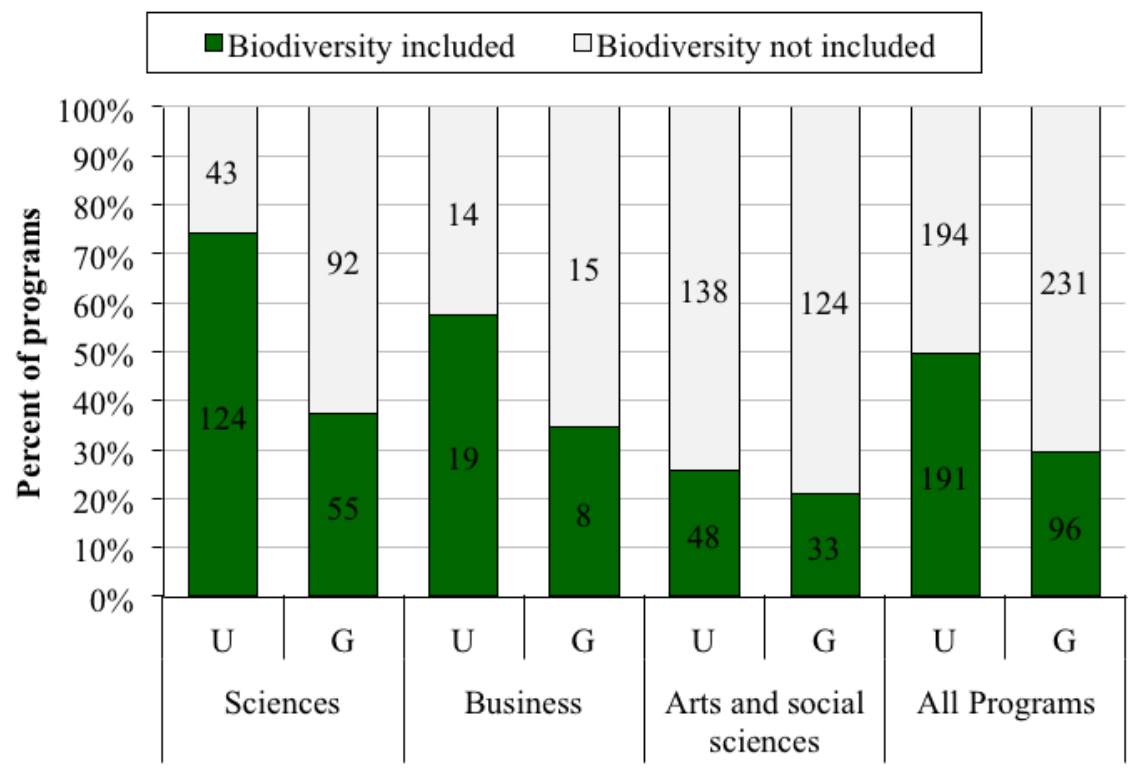

Figure 2: Summary of university biodiversity content overall (all programs) and by category (sciences, business, arts, and social sciences) in undergraduate (U) and graduate $(\mathrm{G})$ programs. This graph illustrates the percentage of programs among these six universities that include biodiversity-related content. The numbers represent the number of programs within each category that either integrate or do not integrate biodiversity concepts.

Some programs rarely featured biodiversity descriptors, such as those in fine arts, history, philosophy, psychology, computer science, and information technology. Across the six sampled universities, no undergraduate or graduate programs in fine arts included biodiversity keywords, and there was only one undergraduate program and one graduate program in history that mentioned biodiversity. Only two undergraduate philosophy and two undergraduate psychology program descriptions included keywords.

In computer science, only University of Ontario Institute of Technology's (UOIT) undergraduate program featured biodiversity content because students in this program must take one or two relevant biology prerequisites. All other computer science and all information technology programs lacked any of the biodiversity keywords in their course descriptions. Although history, philosophy, and psychology programs featured few biodiversity keywords, they sometimes included content that specifically highlighted human interactions with nature that were recorded as including biodiversity content.

At some institutions, students may take interdisciplinary programs or choose double majors, and in the process gain exposure to biodiversity concepts. For example, at Trent University students can pursue double majors in combinations as diverse as business and ecology or cultural studies and chemistry. The present study was not able to account for the complex diversity interdisciplinary programs may offer students.

At the University of Guelph, students have the option to specialize in biodiversity within their Bachelor of Science program. This specialization was unique among the sampled universities. Guelph and Toronto universities had courses at both the undergraduate and graduate levels with the word biodiversity in the title. At the University of Guelph, these two courses are first-year BIOL 1070 Discovering Biodiversity, and a graduate course entitled ENVS 6452 Special Topics in Ecosystem Science and Biodiversity. The University 
of Toronto offers an introductory course, BIO 120H1 Adaptation and Biodiversity, and a graduate course in FOR 3001H, Biodiversity of Forest Organisms.

UOIT offers several engineering courses featuring biodiversity descriptors. This is the case for both undergraduate and graduate courses. For example, two third-year courses are entitled ENGR 3420 Energy and Environmental Impact and ENGR 3570 Environmental Effects of Radiation, and UOIT offers graduate courses in ENGR 5014 Pollution Prevention and Sustainable Engineering and NUCL 5080 Advanced Topics in Environmental Degradation of Materials.

Lakehead University and UOIT offer graduate courses that connect health and environment. These courses are Health Science 5213 Environmental and Occupational Public Health (Lakehead) and HLSC 5314 Environmental Determinants of Health (UOIT). These programs were notable because they connect human health to environmental conditions. The course description for Health Science 5213 reads, "Sample topics to be covered may include toxicology, risk assessment, and human influences on Public Health through development, pollution, and climate change" (Lakehead University, 2014). The University of Toronto features similar Masters and PhD programs in environment and health to bridge these two fields.

Two universities offer degree programs in sustainability. Lakehead's offers a Bachelor of Arts and Sciences in Environmental Sustainability; Trent University offers a Master of Arts in Sustainability Studies. Lakehead also offers a specialization in Environmental and Sustainability Education within its Master of Education for Change program. These findings suggest that the term sustainability may be gaining popularity within postsecondary curricula.

As demonstrated in this study, biodiversity concepts can be integrated within all three academic program categories: sciences, business, and arts and social sciences. Yet, less than one-third of all graduate programs and less than one-half of all undergraduate programs include biodiversity-related content in calendar descriptions. Arts and social sciences programs especially feature little biodiversity integration, and there is still scope for greater integration within business programs.

\section{Discussion}

There are growing calls for postsecondary education to meet the challenge of preparing students for a world where sustainable practice is a priority. Stewart (2010) suggests that universities should require all of their students, irrespective of academic discipline, to complete at least one sustainability-focused course. Scott and Gough (2007) see universities as having a central role as agents of change: "higher education in particular is seen as a focal point to help catalyze a sophisticated, action-orientated conversation regarding global sustainability, as well as create sustainable solutions for the future" (p. 107). The valuing and protection of biodiversity is a central part of sustainability, so the degree to which universities incorporate biodiversity themes in their programs is a key indicator of intent to meet these challenges.

\section{Patterns}

In this research, examples of integrated biodiversity content were found across all categories of academic programming. This may not be surprising given that all of the 
universities in the study have made public commitments to enact sustainable practices and policies. All six universities have a sustainability office and three of the six (Carleton, Guelph, Lakehead) are signatories to the Talloires Declaration (University Leaders for a Sustainable Future, n.d.) with its ten-point action plan that includes a commitment to foster environmentally responsible citizenship and to foster environmental literacy for all. It is clear that there exists the potential to incorporate biodiversity-related content into any postsecondary program. Whether this happens in a particular program presumably depends on a number of factors. The first of these must be faculty members' level of awareness of how biodiversity-related themes relate to the discipline. If faculty members have never considered the link between their academic discipline and biodiversity, then they are unlikely to perceive a need to modify programming to incorporate biodiversity content. Second, even when an awareness of linkage exists, there needs to be a willingness to incorporate such themes. Third, there needs to be the capacity to incorporate biodiversity themes into course material, through faculty expertise and in terms of faculty and administrative support, cooperation, and encouragement between departments.

As anticipated, biodiversity content is prevalent in the life sciences, but it was also found to have a presence in many other science programs such as the physical sciences and engineering. However, some science disciplines show very little evidence of biodiversity inclusion, most notably computer science. This can be viewed as an important deficiency for several reasons:

- Computer science graduates are likely to play a central role in the development of many new technologies.

- Some of these technologies may negatively impact biodiversity, for instance by stimulating a market for raw materials that can only be extracted by mining in ecologically sensitive areas.

- Other technological applications may improve sustainable outcomes that help to maintain biodiversity, for instance through the development of software that enables more energy-efficient practices.

The virtual absence of biodiversity-related programming in computer sciences programs can, therefore, be seen as a significant deficiency.

Unfettered economic development poses a great threat to biodiversity. The impossibility of permanent economic growth on a planet with finite resources is at odds with many traditional business practices and models used in economics. Governments at all levels can be tempted to sacrifice long-term biodiversity for short-term economic gain. It is particularly important, therefore, that business studies programs face up to and address these issues, and challenge unsustainable practices and attitudes within the business sector. Fortunately, this research found that several business studies programs included courses with biodiversity-related themes. This is a positive and hopeful finding that reveals awareness, willingness, and expertise exist and have the potential to engage with the topic in this critical academic discipline.

The relatively low incidence of biodiversity-related content in arts and social science programming is not particularly surprising given the traditional emphases of the disciplines coming under this heading. Yet, as with other programs, examples were found that demonstrate relevant themes are being successfully incorporated. Given the impact on public perceptions that practitioners in the literary, visual, and performing arts can have, it is highly desirable that the integration of biodiversity themes be encouraged in these fields. 


\section{Advantages of the Survey Technique}

Summaries of program content, such as those published by the Council of Ontario Universities (2013) are superficial in that they provide little detailed analysis of program composition or comparative data. Identifying programs that have sustainability content as a stated major or minor only gives part of the picture because it overlooks programs that have smaller, but relevant components. Smith et al. (2011) used a simple keyword search to determine invasive alien species content within Canadian university curricula. While this approach takes little time to complete, it risks missing subtle clues to relevant content. By using a wide range of relevant keywords and digging deeply using a full scan of academic calendars, the present survey has allowed a more detailed picture of biodiversity content in postsecondary education in Ontario to emerge. For example, it would be easy to assume that arts and social science programs generally lack biodiversity content, but the analysis used in this study allowed for a more nuanced understanding, showing that a number of arts and social science programs do address the theme.

The method used in this research is versatile, proving appropriate for the analysis of PDF and online academic calendars. It could also be used with printed academic calendars, providing close attention is paid to locating key words.

\section{Limitations of the Technique}

Although the technique involves the analysis of all courses offered by an institution, it only assesses their content on the basis of course titles and descriptions that appear in academic calendars. This provides only limited insight into what is actually taught in the classroom. Descriptions in academic calendars are, necessarily, brief and may sometimes be outdated and no longer accurately reflect the content of the course. Limited enrolments, faculty sabbaticals, and other logistical factors may result in a course being listed in an academic calendar, but not actually taught. A greater depth of understanding could be obtained by approaching teaching faculty directly, either to interview them or ask them to complete a questionnaire about their course content. These approaches would be vastly more timeconsuming, expensive, and subject to the willingness of faculty members to participate. It is also worth noting that this research involved a binary coding system to determine whether a course included biodiversity keywords. Courses were assessed as either containing biodiversity concepts, or not. Yet, this system did not grade courses based on the extent to which they cover biodiversity concepts. In other words, a course that included multiple keywords (e.g., environment, ecosystem, genetic diversity) was graded the same for biodiversity content (i.e., content present) as a course that included only one keyword (e.g., environment).

Another limitation of this research is that it does not show how many students enrol in each program at each university. Thus, this research does not provide information on the number of students who are exposed to biodiversity education at these universities, and this remains a worthwhile topic to pursue in future studies.

The method used proved time-consuming because of its relatively in-depth analysis of curricula. Approximately 95 hours were spent analyzing the 386 undergraduate and 327 graduate programs (and approximately 18,000 courses) of the six universities surveyed. It was originally hoped that all universities in Ontario would be surveyed, but this was not viable given the funding and time available. 
It is also worth noting that this technique did not attempt to identify how programs addressed the topic of biodiversity within their course content; rather it only assessed whether or not biodiversity content was present. However, it was observed that in general, science programs provided the background scientific knowledge of biodiversity concepts (e.g., ecosystem structures and functions), while arts and social science and business programs focused on human interactions with biodiversity. Future research is recommended to establish quantitative baseline data about the type of biodiversity content within university programs.

\section{Implications of this Research}

The growing threats to biodiversity, whether from gradual encroachment on natural habitats, climate change, or the careless introduction of non-native species, need urgent attention. For this to happen on the scale required, a sea change in attitudes is required from those in positions of power and influence, and in the choices made by the public.

The results of this survey are published in the State of Ontario's Biodiversity Report 2015 (McCallum, Elliott, \& McIntosh, 2014). These findings will help the Ontario Biodiversity Council monitor its success in meeting part of the first target of the Ontario Biodiversity Strategy: the integration of biodiversity into postsecondary curricula. Success in meeting this target will help the Province of Ontario contribute to achieving federal goals and targets, and global biodiversity targets in response to the Aichi Biodiversity Targets (United Nations, 2014). Promoting biodiversity education in postsecondary institutions is likely to be an effective way to reach people who will go on to become influential leaders and decision-makers in society in a diversity of fields including business, education, planning, and politics.

With a detailed analysis of biodiversity-related content from a large sample of postsecondary courses, there is now baseline data against which progress can be measured. By showing that biodiversity content can be appropriately integrated into any academic discipline, it is possible to promote examples of good practice and encourage others to review their program content. The Ontario Biodiversity Council and others can use the data generated by this study to make the case for biodiversity inclusion within postsecondary education in the province. This study also offers a model for other jurisdictions wishing to assess and monitor the education sector's contribution to increasing biodiversity awareness.

\section{Acknowledgements}

We would like to thank Alan Dextrase from the Ontario Ministry of Natural Resources and Forestry for his guidance, assistance, and advice throughout this study, and the Ontario Biodiversity Council for providing funding for this research. In addition, we would like to thank Tom Whillans (Trent University) and Todd Barr (Trent Community Research Centre) for connecting us to this research project, and for their recommendations on our draft.

\section{References}

Baillie, J., Hilton-Taylor, C., Stuart, S. N. (Eds.) (2004). 2004 IUCN Red List of threatened species: A global species assessment. Cambridge, UK: IUCN Publication Services Unit. Retrieved from https://portals.iucn.org/library/node/9830 
Biodiv Canada.ca (2015). 2020 Biodiversity goals and targets for Canada. Retrieved from www.biodivcanada.ca

Canadian Wildlife Federation (n.d.) About the Canadian Wildlife Federation. Retrieved from http://cwf-fcf.org

Carleton University. (2014a). 2013-2014 Undergraduate calendar archives. Retrieved from http://calendar.carleton.ca/archives/

Carleton University. (2014b). Graduate calendar. Retrieved from http://calendar. carleton.ca/archives/

Carson, R. (1962). Silent spring. Boston, MA: Houghton Mifflin.

Council of Ontario Universities. (2013). Growing greener campuses at Ontario universities: 2013 report. Retrieved from http://cou.on.ca/reports/growing-greenercampuses-2013/

Council of Ontario Universities. (2014). Applications \& enrolment. Retrieved from http://www.cou.on.ca/applications-enrolment

Dwyer, M. (2013). Measuring excellence: Details of how Maclean's ranks 49 universities each year. Maclean's magazine. Retrieved from http://www.macleans.ca/education/ unirankings/measuring-excellence-2-2/

Grundy, J. (2013) Environmental Charities in Canada. Toronto, ON: Charity Intelligence Canada.

High Park Nature. (2014). Black oak savannah restoration. Retrieved from www. highparknature.org

Kassas, M. (2002). Environmental education: Biodiversity. Environmentalist, 22(4), 345-351.

Lakehead University. (2014). Lakehead 2014-2015: Academic programs. Retrieved from http://navigator.lakeheadu.ca/Catalog/ViewCatalog.aspx?pageid=viewcatalog\&cat alogid $=20 \&$ chapterid $=3276 \&$ loaduseredits $=$ False

Lozano, R. \& Peattie, K. (2009). Developing a tool to audit curricula contributions to sustainable development. In W. Leal Filho (Ed.). Sustainability at UniversitiesOpportunities, Challenges, and Trends (pp.179-194). Frankfurt am Main, Germany: Peter Lang.

Lozano, R. \& Peattie, K. (2011). Assessing Cardiff University's curricula contribution to sustainable development using the STAUNCH system. Journal of Education for Sustainable Development, 5(1), 115-128.

McCallum, J., Elliott, P., \& McIntosh, T. (2014). Integration of biodiversity into the curricula of select Ontario universities. State of Ontario's Biodiversity Technical Report Series, Report \#SOBTR-01. Ontario Biodiversity Council, Peterborough, ON. Retrieved from http://sobr.ca/_biosite/wp-content/uploads/SOBTR-o1-Final1.pdf

Monastersky, R. (2014). Biodiversity: Life-a status report. Nature, 516 (7530), 159-161.

Ontario Biodiversity Council. (2010). State of Ontario's biodiversity 2010: Highlights report. Peterborough, ON: Ontario Biodiversity Council. 
Ontario Biodiversity Council. (2011). Ontario biodiversity strategy: Renewing our commitment to what sustains us. Peterborough, ON: Ontario Biodiversity Council.

Ontario Biodiversity Council. (2015). State of Ontario's biodiversity. Ontario Biodiversity Council, Peterborough, Ontario. Retrieved from http:// ontariobiodiversitycouncil.ca/sobr

Ontario Ministry of Natural Resources and Forestry. (2014). Species at risk in Ontario list. Retrieved from http://www.ontario.ca/environment-and-energy/species-risk-ontariolist

Ontario Universities' Application Centre. (2015). Links to Ontario universities. Retrieved from http://www.ouac.on.ca/unilinks/

Pimm, S. L., Jenkins, C. N., Abell, R., Brooks, T. M., Gittleman, J. L., Joppa, L. N., \& Sexton, J. O. (2014). The biodiversity of species and their rates of extinction, distribution, and protection. Science, 344(6187), $124675^{2}$.

Schumacher, E. F. (1973). Small is beautiful. London, UK: Blond and Briggs.

Scott, W., \& Gough, S. (2007). Universities and sustainable development: The necessity for barriers to change. Perspectives, 11(4), 107115.

Secretariat of the Convention on Biological Diversity. (2007). Biodiversity and climate change. Montreal, QC: Secretariat of the Convention on Biological Diversity.

Secretariat of the Convention on Biological Diversity. (2008). Biodiversity and agriculture. Safeguarding biodiversity and securing food for the world. Montreal, QC: Secretariat of the Convention on Biological Diversity.

Secretariat of the Convention on Biological Diversity. (2014). Global Biodiversity Outlook 4- Summary and Conclusions. Montreal, QC: Secretariat of the Convention on Biological Diversity.

Smith, A. L., Bazely, D. R., \& Yan, N. D. (2011). Missing the boat on invasive alien species: A review of post-secondary curricula in Canada. Canadian Journal of Higher Education, 41(1), 34-47.

Statistics Canada. (2015a). Canadians and nature: Environmental engagement, 2013. Ottawa, ON: Statistics Canada.

Statistics Canada. (2015b). Population by year, by province and territory (Number). Retrieved from http://www.statcan.gc.ca/tables-tableaux/sum-som/lo1/csto1/demoo2aeng.htm

Stewart, M. (2010). Transforming higher education: A practical plan for integrating sustainability education into the student experience. Journal of Sustainability Education, 1, 195-203.

Trent University. (2014). Academic calendar 2014-2015 undergraduate and graduate programs. Retrieved from http://www.trentu.ca/calendar/

United Nations. (n.d.). Aichi Biodiversity Targets. Retrieved from https://www.cbd. int/sp/targets/

United Nations. (1992). Convention on biological diversity. Retrieved from https:// www.cbd.int/doc/legal/cbd-en.pdf 
United Nations. (2014). Decade on biodiversity. Retrieved from https://www.cbd. int/2011-2020/

Universities Canada. (2015). Universities: Facts and Stats. Retrieved from http:// www.univcan.ca/universities/facts-and-stats/

University Leaders for a Sustainable Future (n.d). Talloires declaration. Retrieved from http://ulsf.org/talloires_declaration.html

University of Guelph. (2014). Academic calendars. Retrieved from http://www. uoguelph.ca/academics/calendars/

University of Ontario Institute of Technology. (2014). Undergraduate and graduate calendars. Retrieved from http://uoit.ca/main/current-students/academics/academiccalendars/academic-calendar-archive/index.php

University ofToronto.(2014b). Faculty of Arts and Science 2013-2014 calendar. Retrieved from http://www.artsandscience.utoronto.ca/ofr/calendar/archived/1314calendar/index. html

University of Toronto. (2014c). School of Graduate Studies academic calendar 2013-2014. Retrieved from http://www.sgs.utoronto.ca/Documents/2013-2014-SGSCalendar.pdf

Wilson, E.O. (1992). The diversity of life. Boston, MA: Belknap Press, Harvard University Press.

\section{Contact Information}

Terese McIntosh

Ministry of Natural Resources and Forestry

terese.mcintosh@ontario.ca

Jenn McCallum is a recent graduate of Trent University's MA Sustainability Studies program. She also holds a Graduate Diploma in Science Communication from Laurentian University, and a BSc in biology from the University of Guelph. Jenn has worked in environmental monitoring, outreach, and education for organizations including Parks Canada, Science North, and Otonabee Region Conservation Authority. She has a special interest in snakes and insects, and enjoys helping audiences learn about the potential to overcome fear of these species.

Paul Elliott is a professor in the School of Education and Professional Learning at Trent University. His current teaching and research interests lie in the fields of science education and environmental education. He has a long-standing interest in biodiversity education, has studied beetles and bats, and presently serves on the steering committee of Ontario's Biodiversity Education and Awareness Network (BEAN).

Terese McIntosh is a natural heritage coordinator on biodiversity and wetlands conservation with the Ontario Ministry of Natural Resources and Forestry. In this position, Terese has been directly involved in the development of Ontario's biodiversity strategy, the On- 
tario government plan to conserve biodiversity, and the reporting efforts on the state of Ontario's biodiversity. Terese completed her PhD in ecology at Trent University, with a focus on large mammal restoration. 